Article

\title{
Prevalence and Characteristics of Listeria monocytogenes Isolates in Raw Milk, Heated Milk and Nunu, a Spontaneously Fermented Milk Beverage, in Ghana
}

\author{
James Owusu-Kwarteng ${ }^{1, *}$, Alhassan Wuni ${ }^{2}$, Fortune Akabanda ${ }^{1}$ and Lene Jespersen ${ }^{3}$ (i) \\ 1 Department of Applied Biology, Faculty of Applied Sciences, University for Development Studies, \\ P.O. Box 24, Navrongo Campus, Ghana; fakabanda@uds.edu.gh \\ 2 Department of Biotechnology, Faculty of Agriculture, University for Development Studies, P. O. Box TL 1882, \\ Nyankpala, Ghana; alhassanwuni@yahoo.com \\ 3 Department of Food Science, University of Copenhagen, Rolighedsvej 26, DK 1958 Frederiksberg C, \\ 1958 Copenhagen, Denmark; lj@food.ku.dk \\ * Correspondence: jowusukwarteng@uds.edu.gh; Tel.: +233-209-265-738
}

Received: 20 April 2018; Accepted: 21 May 2018; Published: 23 May 2018

\begin{abstract}
Listeria monocytogenes is a gram-positive food-borne pathogen that causes listeriosis in humans. Currently, there is little information on the prevalence of Listeria monocytogenes in raw milk and traditional yoghurt-like milk beverage, nunu, in Ghana. The purpose of this study was to investigate the prevalence of L. monocytogenes isolates in raw cow milk, boiled milk and nunu in Ghana, and to characterize these L. monocytogenes isolates according to their serogroups, virulence potentials and antibiotic susceptibility profiles. A total of 254 samples comprising 114 raw cow milk, 56 boiled milk and 84 nunu were collected from dairy farms and market vendors for detection of L. monocytogenes. The overall prevalence of $L$. monocytogenes in raw milk, boiled milk and nunu was $5.5 \%(14 / 254)$. Listeria monocytogenes was prevalent in raw cow milk $(8.8 \% ; 10 / 114)$ and nunu (13.1\%; 11/84), while no Listeria spp. was not detected in boiled milk. A total of $62 \mathrm{~L}$. monocytogenes isolates were analysed to belong to molecular serogroups 1/2a-3a $(32 / 62,51.6 \%), 1 / 2 b-3 b-7(14 / 62$, $22.6 \%), 4 \mathrm{~b}-4 \mathrm{~d}-4 \mathrm{e}(9 / 62,14.5 \%)$ and $1 / 2 \mathrm{c}-3 \mathrm{c}(7 / 62,11.3 \%)$. All $62 \mathrm{~L}$. monocytogenes isolates harbored the virulence-associated genes inlA, inlB, inlC, inlJ, plcA, actA, hlyA, iap and prfA. All Listeria monocytogenes in the present study were generally susceptible to the tested antibiotics, except neomycin and tetracycline, for which phenotypic resistance was observed among isolates.
\end{abstract}

Keywords: dairy products; food safety; virulence genes; antimicrobial resistance; listeria

\section{Introduction}

Listeria monocytogenes is a gram positive, facultative intracellular food-borne pathogen that can cause listeriosis in humans, especially in people of compromised immunity, including the elderly, pregnant women and newborns [1,2]. The bacterium is widespread in nature and can survive and grow under low temperatures and $\mathrm{pH}$, high concentrations of salt or bile, oxidative stress, carbon starvation, and other adverse conditions making it a potential hazard in foods [3]. L. monocytogenes has been isolated from different raw and ready-to-eat (RTE) foods and in raw milk and dairy products in different countries [4-6]. Several cases of listeriosis in humans are reported, sometimes with a high case-fatality rates [7].

Currently, thirteen (13) different serotypes of L. monocytogenes strains have been identified but serotypes $1 / 2 \mathrm{a}, 1 / 2 \mathrm{~b}, 1 / 2 \mathrm{c}$ and $4 \mathrm{~b}$ are responsible for about $95 \%$ of human listeriosis [8,9]. To evaluate 
the potential implications of isolated L. monocytogenes for food safety and public health, it is necessary to differentiate between virulent and non-virulent strains [10]. Many supposed virulence markers such as internalins $(i n l A, i n l B, i n l C$, inlJ), listeriolysin $\mathrm{O}($ hly $A)$, actin (act $A)$, phosphatidylinositol-phospholipase $\mathrm{C}$ (PI-PLC, plcA), Iap (invasion associated protein, iap) and virulence regulator ( $p r f A$ ) have been implicated in the pathogenicity of L. monocytogenes [11-13].

Generally, L. monocytogenes isolates are susceptible to many antibiotics, especially ampicillin/penicillin which are the primary antibiotics for treating listeriosis [14,15]. However, resistance to single or multiple antibiotics have recently been reported for L. monocytogenes strains isolated from various food and environmental sources [6,16-18]. It is, therefore, necessary to intensify research aimed at increasing the available data on the prevalence and antibiotic susceptibility of L. monocytogenes isolates from various food and environmental sources around the world.

In Ghana, cow milk may be consumed in its raw form, heated or processed by spontaneous fermentation into a yoghurt-like beverage known as nunu [19-21]. Poor control measures in the Ghanaian dairy chain potentially exposes raw cow milk and its products to possible contamination by pathogenic microorganisms such as L. monocytogenes, which has implications for the safety of consumers of raw milk and traditional dairy products in Ghana. Appiah et al. [20] reported on the quantitative probabilistic assessment of L. monocytogenes exposure among consumers of milk in Ghana. In general, however, there is limited data that can be used for the qualitative and/or quantitative assessment of the risk of L. monocytogenes infection associated with the consumption of raw milk and traditional dairy products in Ghana. The problem of limited data is compounded by the lack of a proper surveillance systems for food-borne diseases to provide reliable information on the burden of food-borne illnesses, particularly those involving L. monocytogenes associated with milk and milk products in Ghana. Consequently, a number of illnesses or sporadic outbreaks associated with the consumption of Listeria contaminated raw milk and milk products may go unreported. Therefore, the objectives of this study were to determine the prevalence of L. monocytogenes in raw milk, heated milk and nunu in Ghana and to characterize the isolated L. monocytogenes according to their molecular serogroups, antibiotic susceptibility profiles and virulence potential.

\section{Materials and Methods}

\subsection{Samples}

A total of 326 samples comprising 114 raw cow milk, 56 boiled milk and 84 nunu (spontaneously fermented yoghurt-like milk beverage) were purchased from dairy farms and open markets in the Northern Region of Ghana between September 2015 and July 2016. Raw milk samples were collected within 10 min. of milking at the dairy farm while boiled milk and nunu samples were collected at point of sale in the market. Prior to sampling, all samples were stored at ambient temperatures $\left(28 \pm 2{ }^{\circ} \mathrm{C}\right)$. All samples were collected aseptically and immediately transported in a cool box stored at $4.0 \pm 0.5^{\circ} \mathrm{C}$ to the laboratory (Savana Agricultural Research Institute, Tamale-Ghana) for analysis. Samples were kept at $4{ }^{\circ} \mathrm{C}$ and analyzed within $24 \mathrm{~h}$ of collection. The $\mathrm{pH}$ of samples was determined upon delivery to the laboratory using a pH meter (Crison basic 20, Barcelona, Spain) calibrated with standard buffers.

\subsection{Isolation and Characterization of L. monocytogenes}

Isolation and identification of L. monocytogenes in this study was carried out as described by Becker et al. [22]. Briefly, a $25 \mathrm{~g}$ or $25 \mathrm{~mL}$ of each sample was aseptically homogenized in $225 \mathrm{~mL}$ of Listeria enrichment broth base (CM 0862, Oxoid Ltd., Basingstoke, UK) with selective enrichment supplement (SR 0141, Oxoid Ltd., Basingstoke, UK) in Stomacher bags (Seward Ltd., Worthing, UK) for $30 \mathrm{~s}$ using a Stomacher (BagMixer, Buch \& Holm A/S, Interscience, 78860 St Nom, France), followed by incubation at $30{ }^{\circ} \mathrm{C}$ for $24 \mathrm{~h}$. Second enrichment was done by adding $0.1 \mathrm{~mL}$ of the overnight culture to $10 \mathrm{~mL}$ of Listeria enrichment broth base (Oxoid, Basingstoke, UK) with selective enrichment supplement (Oxoid, Basingstoke, UK) and incubated at $37^{\circ} \mathrm{C}$ for $48 \mathrm{~h}$. Subsequently, $0.1 \mathrm{~mL}$ of the 
enriched broth was surface plated on Listeria selective oxford agar (CM0856, Oxoid, Basingstoke, UK) plates supplemented with Listeria selective supplement (SR0140, Oxoid, Basingstoke, UK). Inoculated plates were incubated at $37^{\circ} \mathrm{C}$ for $24-48 \mathrm{~h}$. Presumptive Listeria spp. were identified on oxford agar plates after $24 \mathrm{~h}$ incubation as colonies with approximately $1 \mathrm{~mm}$ diameter, grey to black colonies surrounded by a black halo. Following 48 -h incubation period, typical Listeria species colonies were approximately $2-3 \mathrm{~mm}$ diameter, black with a black halo and sunken center.

For biochemical identification of L. monocytogenes, up to five (5) presumptive colonies from each positive plate were streaked on tryptic soy agar (Oxoid, Basingstoke, UK) supplemented with $0.6 \%$ yeast extract (Oxoid, Basingstoke, UK) (TSA-YE) and incubated at $35^{\circ} \mathrm{C}$ for $24 \mathrm{~h}$. The colonies from TSA-YE plates were confirmed by biochemical tests including Gram staining, catalase, oxidase, triple sugar iron (TSI), sulphide-idole-motility (SIM), methyl-red Voges-Proskauer (MR-VP) reaction, nitrate reduction, and production of acid from rhamnose, xylose, mannitol and $\alpha$-methyl-D-mannopyranoside. Listeria monocytogenes ATCC 19115 was used as a reference strain for biochemical tests and PCR analysis.

\subsection{PCR-Based Identification of L. monocytogenes}

Following biochemical characterization of Listeria isolates, identities of L. monocytogenes were further confirmed polymerase chain reaction (PCR). Crude DNA was extracted from Listeria isolated in this study and L. monocytogenes ATCC 19115, used as positive control, by direct boiling of a suspension of the cell lysates [23]. PCR was performed to detect the presence of Listeria spp. (LI1/U1) using the specific primer sequences ( $5^{\prime}$-CTCCATAAAGGTGACCCT- $\left.3^{\prime}\right)$ and ( $5^{\prime}$-CAGCMGCCGCGGTAATC- $\left.{ }^{\prime}\right)$ and L. monocytogenes (LM1/LM2) primer sequences (5'-CCTAAGACGCCAATCGAA-3') and (5'-AAGCGCTTGCAACTGCTC-3') [24]. The primers LI1/U1 and LM1/LM2 were used to amplify the highly conserved $16 \mathrm{~S}$ rRNA gene (938 bp) of all Listeria spp. and listeriolysin O gene (702 bp) to detect $L$. monocytogenes, respectively. The PCR reaction was performed in an automatic thermal cycler (Biotron, Göttingen, Germany) under the following optimized cycling conditions: initial denaturation step of 4 min at $95^{\circ} \mathrm{C} ; 30$ cycles of denaturation at $95^{\circ} \mathrm{C}$ for $1 \mathrm{~min}$, annealing at $52^{\circ} \mathrm{C}$ for $45 \mathrm{~s}$, extension at $72{ }^{\circ} \mathrm{C}$ for $2 \mathrm{~min}$; and a final elongation at $72{ }^{\circ} \mathrm{C}$ for $8 \mathrm{~min}$. The PCR products were separated by a submerged $1.5 \%$ agarose gel electrophoresis, stained with ethidium bromide and visualized under UV illumination. A PCR reaction mixture without DNA template was used as negative control for extraneous nucleic acid contamination.

\subsection{Molecular Serotyping of L. monocytogenes}

Listeria monocytogenes were separated into four major serotypes $(1 / 2 \mathrm{a}, 1 / 2 \mathrm{c}, 1 / 2 \mathrm{~b}$ and $4 \mathrm{~b})$ by multiplex-PCR described by Doumith et al. [25] using the five primers sets lmo0737, 1mo1118, ORF2819, ORF2110 and prs. Four groups of serotypes are observed based on PCR results. Serogroups 1/2a-3a and 1/2b-3b-7 displays single fragments, $691 \mathrm{bp}$ and $471 \mathrm{bp}$, with the primers lmo0737 and ORF2819 respectively. Serogroup 1/2c-3c displays two fragments (691 bp and $906 \mathrm{bp}$ ) when amplified with the primer sets $1 \mathrm{mo} 0737$ and $1 \mathrm{mo} 1118$, respectively. Similarly, serogroup $4 \mathrm{~b}-4 \mathrm{~d}-4 \mathrm{e}$ displays two fragments of size $471 \mathrm{bp}$ and $597 \mathrm{bp}$ when amplified with the primers ORF2819 and ORF2120 respectively. All members of the genus Listeria show single fragment of $370 \mathrm{bp}$ when amplified with prs primers.

\subsection{Detection of Virulence Associated Genes in L. monocytogenes}

Detection of the virulence-associated genes in L. monocytogenes was carried out in two separate multiplex PCR assays. Internalin genes (inlA, inlB, inlC, and inlJ), were detected in a multiplex-PCR using primers and cycling conditions described by Liu et al. [26]. For the detection of plcA, actA, hlyA, iap and prfA, PCR assay was carried out as described by Kalorey et al. [27].

\subsection{Determination Antimicrobial Resistance among L. monocytogenes Isolates}

Sixty-two identified L. monocytogenes isolates were tested for their susceptibility to antibiotics using the broth micro-dilution method recommended by the standard criteria of the Clinical and 
Laboratory Standards Institute (CLSI) guidelines M45-A2 for L. monocytogenes [28]. The antibiotics used include Amoxicillin, Ampicillin, Cefepime, Chloramphenicol, Ciprofloxacin, Clindamycin, Doxycycline, Erythromycin, Gentamycin, Kanamycin, Neomycin, Penicillin, Rifampin, Tetracycline, and Vancomycin. MIC was determined by two-fold dilution of antibiotics (in the range of 64 to $0.06 \mu \mathrm{g} / \mathrm{mL}$ ) in cation-adjusted Mueller-Hinton broth (CAMHB, Difco Laboratories) supplemented with 5\% lysed horse blood. The MIC breakpoints used for the interpretation of susceptibility were based on those proposed by Bertsch et al. [16] and Acar et al. [29].

\section{Results and Discussion}

\subsection{Prevalence of L. monocytogenes in Raw Milk, Boiled Milk and Nunu}

In this study, a total of 254 samples of raw milk, boiled milk and nunu were examined for Listeria spp. and Listeria monocytogenes (Table 1). Overall, 44/254 (12.2\%) samples were contaminated with Listeria spp. whereas 14/254 (5.5\%) samples were positive for Listeria monocytogenes. The prevalence of L. monocytogenes among the various samples were $8.8 \%(10 / 114)$ for raw cow milk and $4.7 \%(4 / 84)$ for nunu. No Listeria spp. or L. monocytogenes was detected in boiled milk.

Table 1. Prevalence of Listeria spp. and Listeria monocytogenes in raw milk, boiled milk and nunu.

\begin{tabular}{ccccc}
\hline Product & pH of Samples & $\begin{array}{c}\text { Number of } \\
\text { Samples }\end{array}$ & Listeria spp. (\%) & $\begin{array}{c}\text { Listeria } \\
\text { monocytogenes (\%) }\end{array}$ \\
\hline Raw cow milk & $6.7 \pm 0.2$ & 114 & $20(17.5)$ & $10(8.8)$ \\
Boiled milk & $6.3 \pm 0.4$ & 56 & ND & ND \\
Nunu a & $4.1 \pm 0.9$ & 84 & $11(13.1)$ & $4(4.7)$ \\
Total & NA & 254 & $44(12.2)$ & $14(5.5)$ \\
\hline
\end{tabular}

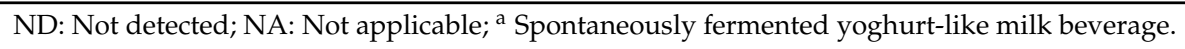

All Listeria spp. and L. monocytogenes isolates from raw milk and nunu samples were confirmed by both biochemical tests and duplex PCR (Figure 1).

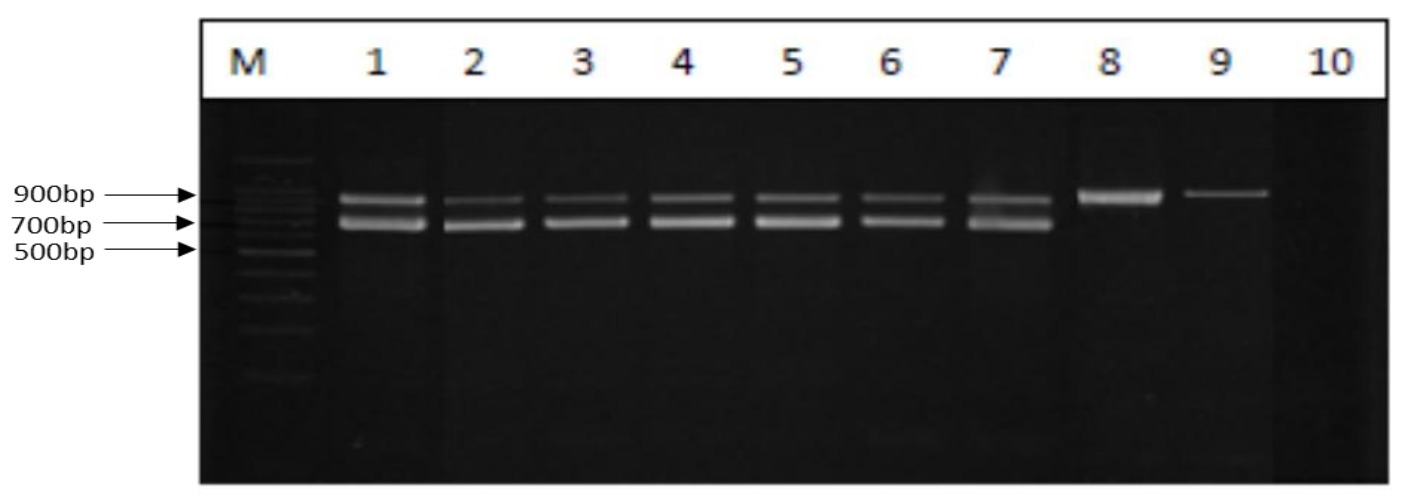

Figure 1. Representative PCR product detecting the highly conserved 16Sr RNA gene sequence for Listeria spp. and listeriolysin O gene sequence for L. monocytogenes. Lane M, 100 bp molecular size DNA marker; lane 1, L. monocytogenes ATCC 19115 (positive control); lanes 2-7, L. monocytogenes isolated from raw cow milk and nunu; lanes 8 and 9, non-L. monocytogenes isolated from raw cow milk and nunu; lane 10, negative control (PCR mixture without DNA template).

Among other human pathogenic microorganisms, L. monocytogenes is considered a major microbiological hazard associated with the consumption of raw cow milk [30,31]. The prevalence of Listeria spp. and Listeria monocytogenes in milk and dairy products, has been widely reported [17,31-33]. The prevalence of L. monocytogenes in milk varies considerably among different survey reports and has 
been attributed to factors such as geographic (environmental) conditions, farm size, farm management practices, sampling and detection methods used among others [30]. In this report, the prevalence of L. monocytogenes in raw cow milk collected from small dairy farms in northern Ghana was $8.8 \%$ while Appiah et al. [20] reported prevalence of over $42 \%$ for raw cow milk sampled from farms in Accra (southern Ghana). According to other previous survey reports, the frequency of detection of L. monocytogenes in raw cow milk can vary from $0 \%$ [34] to more than $45 \%$ [35-40]. Despite the widely reported variation in the prevalence of L. monocytogenes in milk, all the surveys demonstrate that raw cow milk and dairy products can be a source of Listeria infections in humans [30,32].

Listeria monocytogenes occurs widely in agricultural and food processing environments [41] and can contaminate raw milk during milking processes [31]. Additionally, L. monocytogenes is widely distributed in food processing environments with the capacity to tolerate and grow in the temperature range of $0-45^{\circ} \mathrm{C}$ in media with $\mathrm{pH}$ range of 4.4-9.4 [42-44].

Due to the observed high prevalence of L. monocytogenes in raw cow milk from dairy farms in this study, it is possible that the pathogen could enter the processing environments and persist during processing, resulting in the contamination of the dairy products. Nunu is produced by spontaneously fermenting raw cow milk at ambient temperature $\left(28-35^{\circ} \mathrm{C}\right)$ for about $18-24 \mathrm{~h}$ under uncontrolled conditions, bringing the $\mathrm{pH}$ to $4.1 \pm 0.9$ (Table 1). The fermented yoghurt-like milk beverage, nunu, can then be consumed within 4 days after fermentation without refrigeration or refrigerated at $4{ }^{\circ} \mathrm{C}$ for several weeks [21]. The observed prevalence of L. monocytogenes in nunu may be attributed to factors such as post-processing contamination, improper handling of raw milk, or inadequate fermentation to bring the $\mathrm{pH}$ below tolerance levels for L. monocytogenes. Thus, the production of organic acids and bacteriocins which are important natural antimicrobials in nunu, resulting from lactic acid fermentation of milk, might not be sufficient to eliminate L. monocytogenes in the product and therefore should not replace good hygiene practices (practices) during processing. On the other hand, Listeria was not detected in boiled milk, which undergoes thermal treatment without further processing. Boiling is one method that is known to reduce or even eliminate the microbiological risk associated with the consumption of raw milk [30].

\subsection{Molecular Serogroups of L. monocytogenes Isolates}

Based on PCR serotyping, L. monocytogenes isolates belonged to molecular serogroups 1/2a-3a (32/62, 51.6\%), 1/2b-3b-7 (14/62, 22.6\%), 1/2c-3c (7/62, 11.3\%) and 4b-4d-4e (9/62, 14.5\%). Previous reports indicate that over $95 \%$ of the isolates originating from human listeriosis and food samples belonged to serotypes $1 / 2 \mathrm{a}, 1 / 2 \mathrm{~b}, 1 / 2 \mathrm{c}$, and $4 \mathrm{~b}[6,11,45-47]$. Consistent with the previous reports, $51.6 \%$ of L. monocytogenes isolates in this study belonged to serogroup $1 / 2 \mathrm{a}-3 \mathrm{a}$, followed by $1 / 2 \mathrm{~b}-3 \mathrm{~b}-7$ $(22.6 \%), 4 \mathrm{~b}-4 \mathrm{~d}-4 \mathrm{e}(14.5 \%)$ and the $1 / 2 \mathrm{c}-3 \mathrm{c}(11.3 \%)$. The high prevalence and enhanced ability of serotype $1 / 2 \mathrm{a}$ to persist in food environments has been ascribed to the fact that members of this group might be carrying more plasmids which often confer resistance to toxic compounds [48]. Major outbreaks of invasive forms of listeriosis have been associated with serotype $4 \mathrm{~b}$ [49], which has also been isolated from animal-derived foods [6]. Thus, the frequent detection of serotype $4 \mathrm{~b}$ in human listeriosis outbreaks and sporadic cases indicate that these strains may be more virulent than other serotypes.

\subsection{Prevalence of Virulence-Associated Markers}

Irrespective of serotype, all of the sixty-two (62) L. monocytogenes tested harbored the virulence-associated genes inlA, inlB, inlC, and inlJ inlA, inlB, inlC, inlJ, plcA, actA, hlyA, iap and $\operatorname{prf} A$. Listeriolysin $\mathrm{O}$ is reported to be the main bacterial determinant for the escape of $L$. monocytogenes from both primary and secondary vacuoles and is one of its main virulent factors [50,51]. The detection of internalin genes (inlA, inlB, inlC, and $i n l J)$ in almost all examined L. monocytogenes isolates from food samples have been reported [52-55]. The virulence markers InlA, InlC and InlJ, all of which play various roles in L. monocytogenes infections and pathogenesis, are important virulence factors of $L$. 
monocytogenes [11]. In L. monocytogenes, InlA and InlB have evidently been shown to be important for host cell invasion and virulence [56,57]. Furthermore, null mutations in the internalin genes (inlA, inlB, $i n l C$, and inlJ) result in reduced invasion or virulence in tissue culture or animal model studies [58-60], underscoring the important role of these genes in virulence and pathogenesis. In general, the presence of the internalin genes and the other virulence-associated genes in L. monocytogenes isolated from milk and dairy products in Ghana indicates that these L. monocytogenes strain could be potentially virulent.

\subsection{Antibiotic Resistance among L. monocytogenes Isolates}

Phenotypic resistance to 15 antimicrobial agents by 62 L. monocytogenes isolates from raw milk and nunu in Ghana are shown in Table 2. Based on the MIC breakpoints used in this study, L. monocytogenes isolates were generally susceptible to amoxicillin (100\%), ampicillin (100\%), erythromycin $(100 \%)$, gentamycin $(100 \%)$, penicillin $(100 \%)$, rifampicin $(100 \%)$ and vancomycin $(100 \%)$. However, phenotypic resistances were observed against neomycin (61.3\%) and tetracycline (24.2\%), while intermediate susceptibilities were obtained for chloramphenicol, ciprofloxacin, clindamycin, doxycycline, kanamycin, neomycin, streptomycin and tetracycline.

Table 2. Antimicrobial susceptibility profile of L. monocytogenes isolates.

\begin{tabular}{cccccc}
\hline \multirow{2}{*}{ Antimicrobial } & \multicolumn{2}{c}{ a MIC Breakpoints } & \multicolumn{3}{c}{ 任terpretations $\boldsymbol{n}(\mathbf{\%})$} \\
\cline { 2 - 6 } & $\mathbf{S}(\leq)$ & $\mathbf{R}(\geq)$ & $\mathbf{S}$ & $\mathbf{I}$ & $\mathbf{R}$ \\
\hline Amoxicillin & 2 & 8 & $62(100)$ & 0 & 0 \\
Ampicillin & 4 & 8 & $62(100)$ & 0 & 0 \\
Chloramphenicol & 8 & 32 & $60(96.8)$ & $2(3.2)$ & 0 \\
Ciprofloxacin & 2 & 8 & $55(88.7)$ & $7(11.3)$ & 0 \\
Clindamycin & 2 & 8 & $51(82.3)$ & $11(17.7)$ & 0 \\
Doxycycline & 4 & 16 & $58(93.5)$ & $4(6.5)$ & 0 \\
Erythromycin & 2 & 4 & $62(100)$ & $\mathrm{N} / \mathrm{A}$ & 0 \\
Gentamycin & 2 & 8 & $62(100)$ & 0 & 0 \\
Kanamycin & 16 & 64 & $57(91.9)$ & $5(8.1)$ & 0 \\
Neomycin & 8 & 32 & $21(33.9)$ & $3(4.8)$ & $38(61.3)$ \\
Penicillin & 4 & 8 & $62(100)$ & 0 & 0 \\
Rifampicin & 1 & 2 & $62(100)$ & $\mathrm{N} / \mathrm{A}$ & 0 \\
Streptomycin & 8 & 32 & $61(98.4)$ & $1(1.6)$ & 0 \\
Tetracycline & 2 & 8 & $44(70.9)$ & $3(4.8)$ & $15(24.2)$ \\
Vancomycin & 8 & 32 & $62(100)$ & 0 & 0 \\
\hline MIC
\end{tabular}

${ }^{a}$ MIC breakpoint values for all antibiotics against L. monocytogenes were according to the description of Bertsch et al., 2014, except doxycycline and neomycin for which the breakpoints proposed by Acar et al., 1998 were used. ${ }^{\text {b }} \mathrm{S}$ : susceptible; I: intermediate susceptibility; R: resistant.

Listeria monocytogenes is naturally reported to be sensitive to a wide range of antibiotics. However, recent reports show a continuous pattern of emergence of resistant strains [6,14,48]. Listeria monocytogenes from food sources have generally been reported to be highly susceptible to ampicillin, gentamycin, penicillin, rifampicin and vancomycin. On the other hand, varying prevalence of resistance to tetracycline by L. monocytogenes isolates from different food sources have also been reported $[16,53,61,62]$. The high number of L. monocytogenes isolates showing intermediate susceptibility to ciprofloxacin $(11.3 \%)$ and clindamycin $(17.7 \%)$ has similarly been reported by Lyon et al. [63] and Bertsch et al. [16]. Natural populations of several Listeria species have been described as intermediately susceptible to ciprofloxacin and clindamycin [64].

\section{Conclusions}

The results presented in this report demonstrates Listeria monocytogenes is prevalent in raw milk and nunu, a spontaneously fermented yoghurt-like milk beverage, in Ghana. L. monocytogenes isolates from raw milk and nunu in Ghana harbored virulence-associated genes. However, the L. monocytogenes 
isolates were generally susceptible to the different antibiotics tested except tetracycline and neomycin for which phenotypic resistance was observed. However, genotypic assessment of the prevalence of genetic markers associated with antimicrobial resistance for the genetic basis of resistance phenotypes observed in this study would provide a better baseline for further antimicrobial resistance molecular surveillance of L. monocytogenes milk and dairy products in Ghana. Implementation of adequate sanitation program and good hygiene/manufacturing practices (GHP/GMP) for milk production and processing of fermented dairy beverages in Ghana could reduce microbial contamination of these products.

Author Contributions: J.O.-K. conceived the research concept, participated in laboratory experiments, analyzed and interpreted the data and wrote the manuscript. A.W. carried out most of the laboratory experiments and participated in analysis and interpretation of data. F.A. participated in interpretation of data and reviewed the manuscript. L.J. supervised the project and corrected the manuscript. All authors read and approved the content of the manuscript.

Acknowledgments: The work was supported with funding from Danida (Danish International Development Agency, Ministry of Foreign Affairs) and the Government of Ghana (GoG) through the collaborative research project 'Preserving African Food Microorganisms for Green Growth' DFC No. 13-04KU. The authors are also grateful to management of the Savana Agricultural Research Institute (SARI), Tamale-Ghana and Navrongo Health Research Centre (NHRC), Ghana, for granting access to their laboratory facilities.

Conflicts of Interest: The authors declare no conflict of interest in this work.

\section{References}

1. Kang, Q.; Guo, Y.; Hong, S.; Jiang, L. Listeria monocytogenes meningitis in infants: Report of two cases. Chin. J. Contemp. Pediatr. 2013, 15, 1150-1152.

2. Thomas, M.K.; Vriezen, R.; Farber, J.M.; Currie, A.; Schlech, W.; Fazil, A. Economic cost of a Listeria monocytogenes outbreak in Canada, 2008. Foodborne Pathog. Dis. 2015, 12, 966-971. [CrossRef] [PubMed]

3. Razavilar, V.; Genigeorgis, C. Prediction of Listeria spp. growth as affected by various levels of chemicals, $\mathrm{pH}$, temperature and storage time in a model broth. Int. J. Food Microbiol. 1998, 40, 149-157. [CrossRef]

4. Jamali, H.; Chai, L.C.; Thong, K.L. Detection and isolation of Listeria spp. and Listeria monocytogenes in ready-to-eat foods with various selective culture media. Food Control 2013, 32, 19-24. [CrossRef]

5. Rahimi, E.; Ameri, M.; Momtaz, H. Prevalence and antimicrobial resistance of Listeria species isolated from milk and dairy products in Iran. Food Control 2010, 21, 1448-1452. [CrossRef]

6. Wu, S.; Wu, Q.; Zhang, J.; Chen, M.; Hu, H. Listeria monocytogenes prevalence and characteristics in retail raw foods in China. PLoS ONE 2015, 10, e0136682. [CrossRef] [PubMed]

7. Scallan, E.; Crim, S.M.; Runkle, A.; Henao, O.L.; Mahon, B.E.; Hoekstra, R.M.; Griffin, P.M. Bacterial enteric infections among older adults in the united states: Foodborne diseases active surveillance network, 1996-2012. Foodborne Pathog. Dis. 2015, 12, 492-499. [CrossRef] [PubMed]

8. Kathariou, S. Listeria monocytogenes virulence and pathogenicity, a food safety perspective. J. Food Prot. 2002, 65, 1811-1829. [CrossRef] [PubMed]

9. Salcedo, C.; Arreaza, L.; Alcala, B.; De La Fuente, L.; Vazquez, J. Development of a multilocus sequence typing method for analysis of Listeria monocytogenes clones. J. Clin. Microbiol. 2003, 41, 757-762. [CrossRef] [PubMed]

10. Jensen, A.; Thomsen, L.E.; Jørgensen, R.L.; Larsen, M.H.; Roldgaard, B.B.; Christensen, B.B.; Vogel, B.F.; Gram, L.; Ingmer, H. Processing plant persistent strains of Listeria monocytogenes appear to have a lower virulence potential than clinical strains in selected virulence models. Int. J. Food Microbiol. 2008, 123, 254-261. [CrossRef] [PubMed]

11. Shen, J.; Rump, L.; Zhang, Y.; Chen, Y.; Wang, X.; Meng, J. Molecular subtyping and virulence gene analysis of Listeria monocytogenes isolates from food. Food Microbiol. 2013, 35, 58-64. [CrossRef] [PubMed]

12. Soni, D.K.; Singh, M.; Singh, D.V.; Dubey, S.K. Virulence and genotypic characterization of Listeria monocytogenes isolated from vegetable and soil samples. BMC Microbiol. 2014, 14, 241. [CrossRef] [PubMed]

13. Wu, S.; Wu, Q.; Zhang, J.; Chen, M.; Guo, W. Analysis of multilocus sequence typing and virulence characterization of Listeria monocytogenes isolates from Chineseretail ready-to-eat food. Front. Microbiol. 2016, 7, 168. [CrossRef] [PubMed] 
14. Pesavento, G.; Ducci, B.; Nieri, D.; Comodo, N.; Nostro, A.L. Prevalence and antibiotic susceptibility of Listeria spp. isolated from raw meat and retail foods. Food Control 2010, 21, 708-713. [CrossRef]

15. Wieczorek, K.; Dmowska, K.; Osek, J. Prevalence, characterization, and antimicrobial resistance of Listeria monocytogenes isolates from bovine hides and carcasses. Appl. Environ. Microbiol. 2012, 78, 2043-2045. [CrossRef] [PubMed]

16. Bertsch, D.; Muelli, M.; Weller, M.; Uruty, A.; Lacroix, C.; Meile, L. Antimicrobial susceptibility and antibiotic resistance gene transfer analysis of foodborne, clinical, and environmental Listeria spp. isolates including Listeria monocytogenes. MicrobiologyOpen 2014, 3, 118-127. [CrossRef] [PubMed]

17. Chen, M.; Wu, Q.; Zhang, J.; Wu, S.; Guo, W. Prevalence, enumeration, and pheno-and genotypic characteristics of Listeria monocytogenes isolated from raw foods in South China. Front. Microbiol. 2015, 6, 1026. [CrossRef] [PubMed]

18. Soni, D.K.; Singh, R.K.; Singh, D.V.; Dubey, S.K. Characterization of Listeria monocytogenes isolated from Ganges water, human clinical and milk samples at Varanasi, India. Infect. Genet. Evol. 2013, 14, 83-91. [CrossRef] [PubMed]

19. Akabanda, F.; Owusu-Kwarteng, J.; Tano-Debrah, K.; Glover, R.L.; Nielsen, D.S.; Jespersen, L. Taxonomic and molecular characterization of lactic acid bacteria and yeasts in nunu, a Ghanaian fermented milk product. Food Mcrobiol. 2013, 34, 277-283. [CrossRef] [PubMed]

20. Appiah, J.; Tano-Debrah, K.; Annor, G.A.; Alpha, M.M.; Makita, K.; Grace, D. Quantitative probabilistic assessment of the risk of Listeriosis from the consumption of milk from informal markets in Ghana. In Proceedings of the International Congress of Pathogens at the Human-Animal Interface (ICOPHAI), Addis Ababa, Ethiopia, 15-17 September 2011; International Livestock Research Institute (ILRI): Nairobi, Kenya, 2011.

21. Owusu-Kwarteng, J.; Akabanda, F.; Johansen, P.; Jespersen, L.; Nielsen, D.S. Nunu, a West-African fermented yogurt-like milk product. In Yogurt in Health and Disease Prevention; Shah, N.P., Ed.; Elsevier: New York, NY, USA, 2017; pp. 275-283.

22. Becker, B.; Schuler, S.; Lohneis, M.; Sabrowski, A.; Curtis, G.D.; Holzapfel, W.H. Comparison of two chromogenic media for the detection of Listeria monocytogenes with the plating media recommended by EN/DIN 11290-1. Int. J. Food Microbiol. 2006, 109, 127-131. [CrossRef] [PubMed]

23. Thong, K.; Lai, M.; Teh, C.; Chua, K. Simultaneous detection of methicillin-resistant Staphylococcus aureus, Acinetobacter baumannii, Escherichia coli, Klebsiella pneumoniae and Pseudomonas aeruginosa by multiplex PCR. Trop. Biomed. 2011, 28, 21-31. [PubMed]

24. Rossmanith, P.; Krassnig, M.; Wagner, M.; Hein, I. Detection of Listeria monocytogenes in food using a combined enrichment/real-time PCR method targeting the prfA gene. Res. Microbiol. 2006, 157, 763-771. [CrossRef] [PubMed]

25. Doumith, M.; Buchrieser, C.; Glaser, P.; Jacquet, C.; Martin, P. Differentiation of the major Listeria monocytogenes serovars by multiplex PCR. J. Clin. Microbiol. 2004, 42, 3819-3822. [CrossRef] [PubMed]

26. Liu, D.; Lawrence, M.L.; Austin, F.W.; Ainsworth, A.J. A multiplex PCR for species-and virulence-specific determination of Listeria monocytogenes. J. Microbiol. Meth. 2007, 71, 133-140. [CrossRef] [PubMed]

27. Kalorey, D.; Kurkure, N.; Warke, S.; Rawool, D.; Malik, S.; Barbuddhe, S. Isolation of pathogenic Listeria monocytogenes in faeces of wild animals in captivity. Comp. Immunol. Microbiol. 2006, 29, 295-300. [CrossRef] [PubMed]

28. CLSI. Methods for Antimicrobial Dilution and Disk Susceptibility Testing of Infrequently Isolated or Fastidious Bacteria; Approved Guideline (M45-A2); Wayne, P.A., Ed.; Clinical and Laboratory Standards Institute: Wayne, PA, USA, 2010.

29. Acar, J.F.; Bergogne-Berezin, E.; Chabbert, Y.; Cluzel, R.; Courtieu, A.; Courvalin, P.; Veron, M. Communiqué 1992 du Comité de L'Antibiogramme de la Societé Francaise de Microbiologie. Pathol. Biol. 1998, 40, 741-748.

30. Claeys, W.L.; Cardoen, S.; Daube, G.; De Block, J.; Dewettinck, K.; Dierick, K.; De Zutter, L.; Huyghebaert, A.; Imberechts, H.; Thiange, P. Raw or heated cow milk consumption: Review of risks and benefits. Food Control 2013, 31, 251-262. [CrossRef]

31. Verraes, C.; Vlaemynck, G.; Van Weyenberg, S.; De Zutter, L.; Daube, G.; Sindic, M.; Uyttendaele, M.; Herman, L. A review of the microbiological hazards of dairy products made from raw milk. Int. Dairy J. 2015, 50, 32-44. [CrossRef] 
32. Buchanan, R.L.; Gorris, L.G.; Hayman, M.M.; Jackson, T.C.; Whiting, R.C. A review of Listeria monocytogenes: An update on outbreaks, virulence, dose-response, ecology, and risk assessments. Food Control 2017, 75, 1-13. [CrossRef]

33. Nayak, D.N.; Savalia, C.; Kalyani, I.; Kumar, R.; Kshirsagar, D. Isolation, identification, and characterization of Listeria spp. from various animal origin foods. Vet. World 2015, 8, 695. [CrossRef] [PubMed]

34. Stephan, R.; Buhler, K. Prevalence of Campylobacter spp., Salmonella spp. and Listeria monocytogenes in bulk-tank milk samples from north-east Switzerland. Arch. Lebensmittelhyg. 2002, 53, 62-65.

35. De Reu, K.; Grijspeerdt, K.; Herman, L. A Belgian survey of hygiene indicator bacteria and pathogenic bacteria in raw milk and direct marketing of raw milk farm products. J. Food Safety 2004, 24, 17-36. [CrossRef]

36. Domínguez, R.L.; Fernández, G.J.; Vazquez, B.J.; Rodriguez, F.E.; Suarez, F.G. Isolation of micro-organisms of the species Listeria from raw milk intended for human consumption. Can. J. Microbiol. 1985, 31, 938-941.

37. El Marnissi, B.; Bennani, L.; Cohen, N.; Lalami, A.E.O.; Belkhou, R. Presence of Listeria monocytogenes in raw milk and traditional dairy products marketed in the north-central region of Morocco. Afr. J. Food Sci. 2013, 7, 87-91. [CrossRef]

38. Fenlon, D.; Stewart, T.; Donachie, W. The incidence, numbers and types of Listeria monocytogenes isolated from farm bulk tank milks. Lett. Appl. Microbiol. 1995, 20, 57-60. [CrossRef] [PubMed]

39. Meyer-Broseta, S.; Diot, A.; Bastian, S.; Rivière, J.; Cerf, O. Estimation of low bacterial concentration: Listeria monocytogenes in raw milk. Int. J. Food Microbiol. 2003, 80, 1-15. [CrossRef]

40. Waak, E.; Tham, W.; Danielsson-Tham, M.-L. Prevalence and fingerprinting of Listeria monocytogenes strains isolated from raw whole milk in farm bulk tanks and in dairy plant receiving tanks. Appl. Environ. Microbiol. 2002, 68, 3366-3370. [CrossRef] [PubMed]

41. Strawn, L.K.; Fortes, E.D.; Bihn, E.A.; Nightingale, K.K.; Gröhn, Y.T.; Worobo, R.W.; Wiedmann, M.; Bergholz, P.W. Landscape and meteorological factors affecting prevalence of three food-borne pathogens in fruit and vegetable farms. Appl. Environ. Microbiol. 2013, 79, 588-600. [CrossRef] [PubMed]

42. Carpentier, B.; Cerf, O. Persistence of Listeria monocytogenes in food industry equipment and premises. Int. J. Food Microbiol. 2011, 145, 1-8. [CrossRef] [PubMed]

43. Ferreira, V.; Wiedmann, M.; Teixeira, P.; Stasiewicz, M. Listeria monocytogenes persistence in food-associated environments: Epidemiology, strain characteristics, and implications for public health. J. Food Prot. 2014, 77, 150-170. [CrossRef] [PubMed]

44. WHO. Risk Assessment of Listeria monocytogenes in Ready-to-Eat Foods: Interpretative Summary, Food and Agriculture Organization: Rome, Italy, 2004.

45. Althaus, D.; Lehner, A.; Brisse, S.; Maury, M.; Tasara, T.; Stephan, R. Characterization of Listeria monocytogenes strains isolated during 2011-2013 from human infections in Switzerland. Foodborne Pathog. Dis. 2014, 11, 753-758. [CrossRef] [PubMed]

46. Pontello, M.; Guaita, A.; Sala, G.; Cipolla, M.; Gattuso, A.; Sonnessa, M.; Gianfranceschi, M.V. Listeria monocytogenes serotypes in human infections (Italy, 2000-2010). Ann. Dell'ist. Super. Sanitã 2012, 48, 146-150. [CrossRef]

47. Yu, T.; Jiang, X. Prevalence and characterization of Listeria monocytogenes isolated from retail food in Henan, China. Food Control 2014, 37, 228-231. [CrossRef]

48. Korsak, D.; Borek, A.; Daniluk, S.; Grabowska, A.; Pappelbaum, K. Antimicrobial susceptibilities of Listeria monocytogenes strains isolated from food and food processing environment in Poland. Int. J. Food Microbiol. 2012, 158, 203-208. [CrossRef] [PubMed]

49. Buchrieser, C.; Brosch, R.; Catimel, B.; Rocourt, J. Pulsed-field gel electrophoresis applied for comparing Listeria monocytogenes strains involved in outbreaks. Can. J. Microbiol. 1993, 39, 395-401. [CrossRef] [PubMed]

50. Camejo, A.; Carvalho, F.; Reis, O.; Leitão, E.; Sousa, S.; Cabanes, D. The arsenal of virulence factors deployed by Listeria monocytogenes to promote its cell infection cycle. Virulence 2011, 2, 379-394. [CrossRef] [PubMed]

51. Schnupf, P.; Portnoy, D.A. Listeriolysin O: A phagosome-specific lysin. Microbes Infect. 2007, 9, 1176-1187. [CrossRef] [PubMed]

52. Indrawattana, N.; Nibaddhasobon, T.; Sookrung, N.; Chongsa-nguan, M.; Tungtrongchitr, A.; Makino, S.-I.; Tungyong, W.; Chaicumpa, W. Prevalence of Listeria monocytogenes in raw meats marketed in Bangkok and characterization of the isolates by phenotypic and molecular methods. J. Health Popul. Nutr. 2011, 29, 26. [CrossRef] [PubMed] 
53. Jamali, H.; Paydar, M.; Ismail, S.; Looi, C.Y.; Wong, W.F.; Radmehr, B.; Abedini, A. Prevalence, antimicrobial susceptibility and virulotyping of Listeria species and Listeria monocytogenes isolated from open-air fish markets. BMC Microbiol. 2015, 15, 144. [CrossRef] [PubMed]

54. Lomonaco, S.; Patti, R.; Knabel, S.J.; Civera, T. Detection of virulence-associated genes and epidemic clone markers in Listeria monocytogenes isolates from PDO Gorgonzola cheese. Int. J. Food Microbiol. 2012, 160, 76-79. [CrossRef] [PubMed]

55. Sant'Ana, A.S.; Igarashi, M.C.; Landgraf, M.; Destro, M.T.; Franco, B.D. Prevalence, populations and pheno-and genotypic characteristics of Listeria monocytogenes isolated from ready-to-eat vegetables marketed in São Paulo, Brazil. Int. J. Food Microbiol. 2012, 155, 1-9. [CrossRef] [PubMed]

56. Dramsi, S.; Biswas, I.; Maguin, E.; Braun, L.; Mastroeni, P.; Cossart, P. Entry of Listeria monocytogenes into hepatocytes requires expression of inIB, a surface protein of the internalin multigene family. Mol. Microbiol. 1995, 16, 251-261. [CrossRef] [PubMed]

57. Gaillard, J.-L.; Berche, P.; Frehel, C.; Gouln, E.; Cossart, P. Entry of L. monocytogenes into cells is mediated by internalin, a repeat protein reminiscent of surface antigens from gram-positive cocci. Cell 1991, 65, 1127-1141. [CrossRef]

58. Dramsi, S.; Dehoux, P.; Lebrun, M.; Goossens, P.L.; Cossart, P. Identification of four new members of the internalin multigene family of Listeria monocytogenes EGD. Infect. Immun. 1997, 65, 1615-1625. [PubMed]

59. Raffelsbauer, D.; Bubert, A.; Engelbrecht, F.; Scheinpflug, J.; Simm, A.; Hess, J.; Kaufmann, S.; Goebel, W. The gene cluster inlC2DE of Listeria monocytogenes contains additional new internalin genes and is important for virulence in mice. Mol. Gen. Genet. 1998, 260, 144-158. [CrossRef] [PubMed]

60. Sabet, C.; Lecuit, M.; Cabanes, D.; Cossart, P.; Bierne, H. LPXTG protein InlJ, a newly identified internalin involved in Listeria monocytogenes virulence. Infect. Immun. 2005, 73, 6912-6922. [CrossRef] [PubMed]

61. Al-Nabulsi, A.A.; Osaili, T.M.; Shaker, R.R.; Olaimat, A.N.; Jaradat, Z.W.; Elabedeen, N.A.Z.; Holley, R.A. Effects of osmotic pressure, acid, or cold stresses on antibiotic susceptibility of Listeria monocytogenes. Food Microbiol. 2015, 46, 154-160. [CrossRef] [PubMed]

62. Conter, M.; Paludi, D.; Zanardi, E.; Ghidini, S.; Vergara, A.; Ianieri, A. Characterization of antimicrobial resistance of foodborne Listeria monocytogenes. Int. J. Food Microbiol. 2009, 128, 497-500. [CrossRef] [PubMed]

63. Lyon, S.A.; Berrang, M.E.; Fedorka-Cray, P.J.; Fletcher, D.L.; Meinersmann, R.J. Antimicrobial resistance of Listeria monocytogenes isolated from a poultry further processing plant. Foodborne Pathog. Dis. 2008, 5, 253-259. [CrossRef] [PubMed]

64. Troxler, R.; Von Graevenitz, A.; Funke, G.; Wiedemann, B.; Stock, I. Natural antibiotic susceptibility of Listeria species: L. grayi, L. innocua, L. ivanovii, L. monocytogenes, L. seeligeri and L. welshimeri strains. Clin. Microbiol. Infect. 2000, 6, 525-535. [CrossRef] [PubMed] 